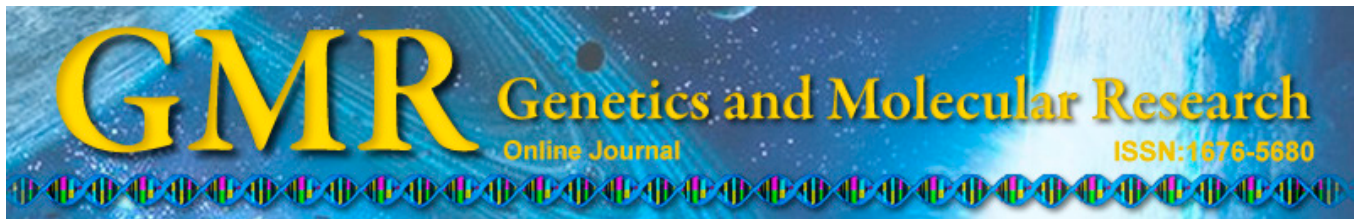

\title{
Development of expressed sequence tag-simple sequence repeat markers for Chrysanthemum morifolium and closely related species
}

\author{
H. Liu, Q.X. Zhang, M. Sun, H.T. Pan and Z.X. Kong \\ Beijing Key Laboratory of Ornamental Plants Germplasm Innovation and \\ Molecular Breeding, National Engineering Research Center for Floriculture, \\ Beijing Laboratory of Urban and Rural Ecological Enviroment, \\ College of Landscape Architecture, Beijing Forestry University, Beijing, China
}

Corresponding author: Q.X. Zhang

E-mail: zqxbjfu@126.com

Genet. Mol. Res. 14 (3): 7578-7586 (2015)

Received January 24, 2015

Accepted April 8, 2015

Published July 13, 2015

DOI http://dx.doi.org/10.4238/2015.July.13.1

\begin{abstract}
With the development of chrysanthemum breeding in recent years, an increasing number of wild species in genera related to Chrysanthemum were introduced to extend the genetic resources and facilitate the genetic improvement of chrysanthemums via hybridization. However, few simple sequence repeat (SSR) markers are available for marker-assisted breeding and population genetic studies of chrysanthemum and closely related species. Expressed sequence tags (ESTs) in public databases and cross-species transferable markers are considered to be a cost-effective means for developing sequencebased markers. In this study, 25 EST-SSRs were successfully developed from Chrysanthemum EST sequences for Chrysanthemum morifolium and closely related species. In total, 4164 unigene sequences were assembled from 7180 ESTs of chrysanthemum in GenBank, which were subsequently used to screen for the presence of microsatellites with the
\end{abstract}


SSRIT software. The screening criteria were $8,5,4$, and 3 repeating units for di-, tri-, tetra-, and penta- and higher-order nucleotides, respectively. Moreover, 310 SSR loci from 296 sequences were identified, and 198 primer pairs for SSR amplification were designed with the Primer Premier 5.0 software, of which 25 SSR loci showed polymorphic amplification in 52 species and varieties belonging to Chrysanthemum, Ajania, and Opisthopappus. The application of EST-SSR markers to the identification of intergeneric hybrids between Chrysanthemum and Ajania was demonstrated. Therefore, EST-SSRs can be developed for species that lack gene sequences or ESTs by utilizing ESTs of closely related species.

Key words: Expressed sequence tag-simple sequence repeat; Chrysanthemum morifolium; Hybrid identification

\section{INTRODUCTION}

Chrysanthemum (Chrysanthemum morifolium) is an economically important ornamental species that comprises a large proportion of the flower industry in many Southeast Asian and European countries. The demand for different chrysanthemums, including cut-flower, garden, potted, and ground-cover types, increases each year (Zhang et al., 2011). Many new varieties are bred each year, including cut chrysanthemum, pot chrysanthemum, and groundcover chrysanthemum. The breeding of new germplasms depends mainly on conventional crossings in the genus Chrysanthemum. Chrysanthemum species and commercial cultivars, ground cover chrysanthemums, which were bred from species $C$. vestitum, $C$. indicum, $C$. zawadskii, C. lavandulifolium, C. nankingense, and C. chanetii and cultivars, compose the primary gene pool of chrysanthemum (Fukai, 2003).

With the development of chrysanthemum breeding in recent years, an increasing number of wild species in genera related to Chrysanthemum were introduced to extend the genetic resources and facilitate the genetic improvement of chrysanthemums via hybridization. Many wild species in Chrysanthemum and closely related genera can be successfully crossed with modern chrysanthemums, which represent important genetic resources for introducing new characteristics to florists' chrysanthemums (Zhao et al., 2009). Reciprocal crosses between chrysanthemum and 10 wild chrysanthemum species (C. articum ssp. maekawanum, C. lavandulifolium, C. crassum, C. indicum, C. japonicum, C. ornatum, C. occidental-japonense var. ashizuriense, C. yoshinaganthum, C. chanetii, and C. pacificum [Ajania pacifica]) were possible when the appropriate parental genotypes were carefully chosen (Fukai et al., 2000). Ajania and Chrysanthemum show some crosscompatibility (Fukai, 2003), and a number of Chrysanthemum and Ajania hybrids have been successfully obtained (Abd El-Twab et al., 1999). Breeding programs for cut flowers have been reported using Ajania species, such as A. pacifica (Shibata et al., 1988) and A. shiwogiku (Douzono and Ikeda, 1998). Five intergeneric hybrids between the chrysanthemum cultivar Zhongshanjingui (as female) and A. przewalskii (as male) were obtained with the help of embryo culture (Deng et al., 2011). The number of natural and artificial intergeneric hybrids between Chrysanthemum and Ajania is so vast that Ohashi and Yonekura (2004) proposed that Ajania, Arctanthemum, and Phaeostigma should be combined into the genus 
of Chrysanthemum (Zhao et al., 2009).

In addition, intergeneric hybrids have been reported between Chrysanthemum and related species from the same subtribe Artemisiinae (Crossostephium chinense) (Kondo et al., 2003). Twenty-three hybrid seedlings have been chosen from the distant hybridization of Taihang chrysanthemum, Chrysanthemum, and Ajania (Hu and Zhao, 2008). Therefore, the species in genera related to Chrysanthemum, such as Ajania and Opisthopappus, are a secondary gene pool for chrysanthemum breeding, and the closely related genera might be increasingly exploited to genetically improve chrysanthemums via hybridization.

Molecular markers have become an indispensable tool for breeding and cultivar development in many crops (Varshney et al., 2005). Markers are frequently required to correctly identify cultivars, accurately assess genetic relationships and diversity, efficiently tag and map desirable genes, and select superior genotypes early (Gong and Deng, 2010). Among the molecular markers, simple sequence repeats (SSRs) have several advantages, such as their relative abundance and random distribution in the genome, their high rates of polymorphism (multiallelic nature), and their Mendelian codominant inheritance (Morgante and Olivieri, 1993). The development of SSRs via the de novo sequencing method is a costly and time-consuming endeavor (Zane et al., 2002). One possible solution to these types of problems would be to exploit publicly available genomic resources for the development of gene-based SSR markers that are more likely to be transferable across taxonomic boundaries (Ellis and Burke, 2007). The rapid and inexpensive development of SSRs from expressed sequence tag (EST) databases has been shown to be a feasible option for obtaining high-quality nuclear markers (Gupta et al., 2003; Bhat et al., 2005). In general, EST-SSRs have been found to be significantly more transferable across taxonomic boundaries than traditional "anonymous" SSRs (Chagné et al., 2004; Gutierrez et al., 2005; Pashley et al., 2006). This transferability is particularly true in plants, where transferability among economically important crop taxa has been demonstrated on a number of occasions (Decroocq et al., 2003; Thiel et al., 2003; Bandopadhyay et al., 2004; Saha et al., 2004; Varshney et al., 2005). Recent research has revealed that ESTs are a potentially rich source of SSRs that reveal polymorphisms not only within the source taxon but also in related taxa (Ellis and Burke, 2007).

However, few SSR markers have been used and developed in Chrysanthemum, and no SSR markers have been exploited in its closely related species or genera, such as Ajania and Opisthopappus. Moreover, few gene sequences or ESTs have been available in these closely related genera of Chrysanthemum.

Thus, our objective was to develop SSR markers from EST databases of Chrysanthemum for Chrysanthemum morifolium and closely related species and genera, which can be employed in molecular marker-assisted breeding, genetic diversity analysis, and other applications.

\section{MATERIAL AND METHODS}

\section{Plant materials and DNA extraction}

In this study, a total of 52 wild species and varieties of Chrysanthemum, Ajania, and Opisthopappus were employed to test the amplification and polymorphism of primer pairs (Table 1). These materials were collected from 14 provinces in the northeast and northwest of China, central China, eastern China, and southern China. Among these samples, Ajania 
pacifica is native to the Taiwanese area of China and Japan. Genomic DNA was isolated from young leaves using an improved cetyltrimethylammonium bromide method (Liu et al., 2003).

Table 1. List of Chrysanthemum, Ajania, and Opisthopappus materials used in this study.

\begin{tabular}{|c|c|c|c|c|}
\hline Genus & Species & Variety & Origin & Notes \\
\hline Chrysanthemum & C. morifolium & $\begin{array}{l}\text { Quanxiangchongtian } \\
\text { Baiou } \\
\text { Lvyishang } \\
\text { Shiyongju } \\
\text { Pubu } \\
\text { Fanxing } \\
\text { Junziyu } \\
\text { Lvmudan } \\
\text { Huige } \\
\text { Meihualu } \\
\text { Xuetao } \\
\text { Feiliuqianchi } \\
\text { Taohongliulv } \\
\text { Fenghuangzhenyu } \\
\text { Jinjihongling } \\
\text { Huangkuilong } \\
\text { Fenditan } \\
\text { Jingqi } \\
\text { Pudifendai } \\
\text { Jinguangwanzhang } \\
\text { Ziyunqinfang } \\
\text { Fanhuasijin } \\
\text { Zhaoyanghong } \\
\text { Jinzhu } \\
\text { Nongfenzhaoxia } \\
\text { Baisha } \\
\text { Danhanfen } \\
\text { Maoxiangyu } \\
\text { Xiangfei } \\
\text { Mibaizao } \\
\text { Pudidanfen } \\
\text { Qinglian } \\
\text { Yaohong } \\
\text { Yangguangxiaoj } \\
\text { Yulong }\end{array}$ & $\begin{array}{l}\text { Beihai Park in Beijing } \\
\text { Beihai Park in Beijing } \\
\text { Beihai Park in Beijing } \\
\text { Beihai Park in Beijing } \\
\text { Beihai Park in Beijing } \\
\text { Beihai Park in Beijing } \\
\text { Beihai Park in Beijing } \\
\text { Beihai Park in Beijing } \\
\text { Beihai Park in Beijing } \\
\text { Beihai Park in Beijing } \\
\text { Beihai Park in Beijing } \\
\text { Beihai Park in Beijing } \\
\text { Beihai Park in Beijing } \\
\text { Beihai Park in Beijing } \\
\text { Beihai Park in Beijing } \\
\text { Beihai Park in Beijing } \\
\text { Beijing Forestry University } \\
\text { Beijing Forestry University } \\
\text { Beijing Forestry University } \\
\text { Beijing Forestry University } \\
\text { Beijing Forestry University } \\
\text { Beijing Forestry University } \\
\text { Beijing Forestry University } \\
\text { Beijing Forestry University } \\
\text { Beijing Forestry University } \\
\text { Beijing Forestry University } \\
\text { Beijing Forestry University } \\
\text { Beijing Forestry University } \\
\text { Beijing Forestry University } \\
\text { Beijing Forestry University } \\
\text { Beijing Forestry University } \\
\text { Beijing Forestry University } \\
\text { Beijing Forestry University } \\
\text { Beijing Forestry University } \\
\text { Beijing Forestry University }\end{array}$ & $\begin{array}{l}\text { Large chrysanthemum } \\
\text { Large chrysanthemum } \\
\text { Large chrysanthemum } \\
\text { Large chrysanthemum } \\
\text { Large chrysanthemum } \\
\text { Escarpment chrysanthemum } \\
\text { Escarpment chrysanthemum } \\
\text { Large chrysanthemum } \\
\text { Large chrysanthemum } \\
\text { Large chrysanthemum } \\
\text { Large chrysanthemum } \\
\text { Large chrysanthemum } \\
\text { Large chrysanthemum } \\
\text { Large chrysanthemum } \\
\text { Large chrysanthemum } \\
\text { Large chrysanthemum } \\
\text { Ground-cover chrysanthemum } \\
\text { Ground-cover chrysanthemum } \\
\text { Ground-cover chrysanthemum } \\
\text { Ground-cover chrysanthemum } \\
\text { Ground-cover chrysanthemum } \\
\text { Ground-cover chrysanthemum } \\
\text { Ground-cover chrysanthemum } \\
\text { Ground-cover chrysanthemum } \\
\text { Ground-cover chrysanthemum } \\
\text { Ground-cover chrysanthemum } \\
\text { Ground-cover chrysanthemum } \\
\text { Ground-cover chrysanthemum } \\
\text { Ground-cover chrysanthemum } \\
\text { Ground-cover chrysanthemum } \\
\text { Ground-cover chrysanthemum } \\
\text { Ground-cover chrysanthemum } \\
\text { Ground-cover chrysanthemum } \\
\text { Ground-cover chrysanthemum } \\
\text { Ground-cover chrysanthemum }\end{array}$ \\
\hline Chrysanthemum & C. indicum & & Korea & \\
\hline Chrysanthemum & C. lavandulifolium & & Anhui Province & \\
\hline Chrysanthemum & C. eticuspe & & Hubei Province & \\
\hline Chrysanthemum & C. chanetii & & Beijing & \\
\hline Chrysanthemum & C. mankingense & & Jiangsu Province & \\
\hline Chrysanthemum & C. indicum & & Hubei Province & \\
\hline Chrysanthemum & C. indicum var. aromaticum & & Hubei Province & \\
\hline Chrysanthemum & C. zawadskii & & Heilongjiang Province & \\
\hline Ajania & A. fruticulosa & & Qinghai Province & \\
\hline Ajania & A. potaninii & & Sichuan Province & \\
\hline Ajania & A. achilloides & & Inner Mongolia & \\
\hline Ajania & A. scharnhorstii & & Xinjiang Province & \\
\hline Ajania & A. khartensis & & Yunnan Province & \\
\hline Ajania & A. purpurea & & Tibet & \\
\hline Ajania & A. acificum & & Taiwan & \\
\hline Opisthopappus & O. taihangensis & & Henan Province & \\
\hline Opisthopappus & O. longilobus & & Hebei Province & \\
\hline
\end{tabular}

\section{Identification of SSR-containing ESTs and primer design}

In February 2012, all of the 7180 ESTs of C. morifolium were downloaded from Gen- 
Bank (up to February 2012) (http://www.ncbi.nlm.nih.gov/Genbank/). A total of 4164 unigene sequences (908 contigs and 3256 singlets) were generated using the CAP3 software. All contigs and singlets were then used to screen for the presence of microsatellites with the SSRIT software (http://www.gramene.org/db/markers/ssrtool). The screening criteria were $8,5,4$, and 3 repeating units for di-, tri-, tetra-, and penta- and higher-order nucleotides, respectively. Three hundred ten SSRs from 296 sequences were identified. One hundred ninety-eight primer pairs in the flanking region of SSRs were successfully designed using the Primer Premier 5.0 software with a length of 18 to $24 \mathrm{bp}$, amplification product size of 100 to $500 \mathrm{bp}$, annealing temperature (Ta) of 40 to $60^{\circ} \mathrm{C}$, and $\mathrm{GC}$ content between 40 and $60 \%$.

\section{Polymerase chain reaction (PCR) amplification and fragment analysis}

PCR was performed in a total volume of $25 \mu \mathrm{L}$, which contained approximately 40 to 60 ng template DNA, $2.5 \mu \mathrm{L}$ 10X PCR buffer, $2.5 \mu \mathrm{L} 25 \mathrm{mM} \mathrm{MgCl}_{2}, 0.4 \mu \mathrm{L} 10 \mu \mathrm{M}$ of each primer, $0.5 \mu \mathrm{L} 10 \mathrm{mM}$ dNTPs, $2 \mathrm{U}$ Taq polymerase (Promega, USA), and sterile distilled water. The PCR amplification was performed on a TECHNE instrument (TC-512, UK) with the following program: $94^{\circ} \mathrm{C}$ for $4 \mathrm{~min}$ (initial denaturation); 30 cycles of $94^{\circ} \mathrm{C}$ for $30 \mathrm{~s}$, the appropriate annealing temperature (Table 2) for $30 \mathrm{~s}$, and $72^{\circ} \mathrm{C}$ for $1 \mathrm{~min}$; and a final extension for 5 minutes at $72^{\circ} \mathrm{C}$.

The PCR products were confirmed on a $\%$ agarose gel with a constant voltage of 100 $\mathrm{V}(85 \mathrm{~mA})$ for 40 minutes using a Bio-Rad electrophoresis system (USA). The amplicons were analyzed using an ABI3130xl genetic analyzer (Applied Biosystems, USA). The allele size was determined as base pairs using the GeneMapper software v3.7 (Applied Biosystems, USA).

\section{RESULTS}

Of these primer pairs, only 25 revealed polymorphism (Table 2) among 52 wild species and varieties of Chrysanthemum, Ajania, and Opisthopappus. The remaining primer pairs did not amplify PCR products or produced complex band patterns, indicating non-specific amplification. Table 2 lists these working EST-SSR markers, repeat motif, optimal annealing temperature, and annotation of putative functions. Each EST-SSR marker name consisted of the prefix CEM (Chrysanthemum EST-derived microsatellite). Nei's gene diversity ranged from 0.0960 to 0.2968 , with an average of 0.2290 ; the average Shannon's information index was 0.2626 in 52 germplasms.

Basic local alignment search tool with translated nucleotide query (BLASTX) searches against the nr protein database (National Center for Biotechnology Information, NCBI) revealed that 7 SSR marker-targeted ESTs have putative gene functions: 1 EST encodes a putative disease-resistance protein, 3 ESTs encode stress-resistance relative proteins, 1 EST encodes a fruit development control protein, 1 EST encodes a growth stage regulatory protein, and 1 EST encodes a DNA repair protein.

\section{Utility of EST-SSRs}

The EST-SSR markers CEM2, CEM4, and CEM9 were randomly selected to identify intergeneric hybrids (Figure 1) of the C. morifolium Pudidanfen (male parent, hexaploid) and A. pacifica (female parent, decaploid), as well as that of C. morifolium Yulong (female parent, hexaploid) and A. pacifica (female parent). 
Development of EST-SSR markers for chrysanthemum

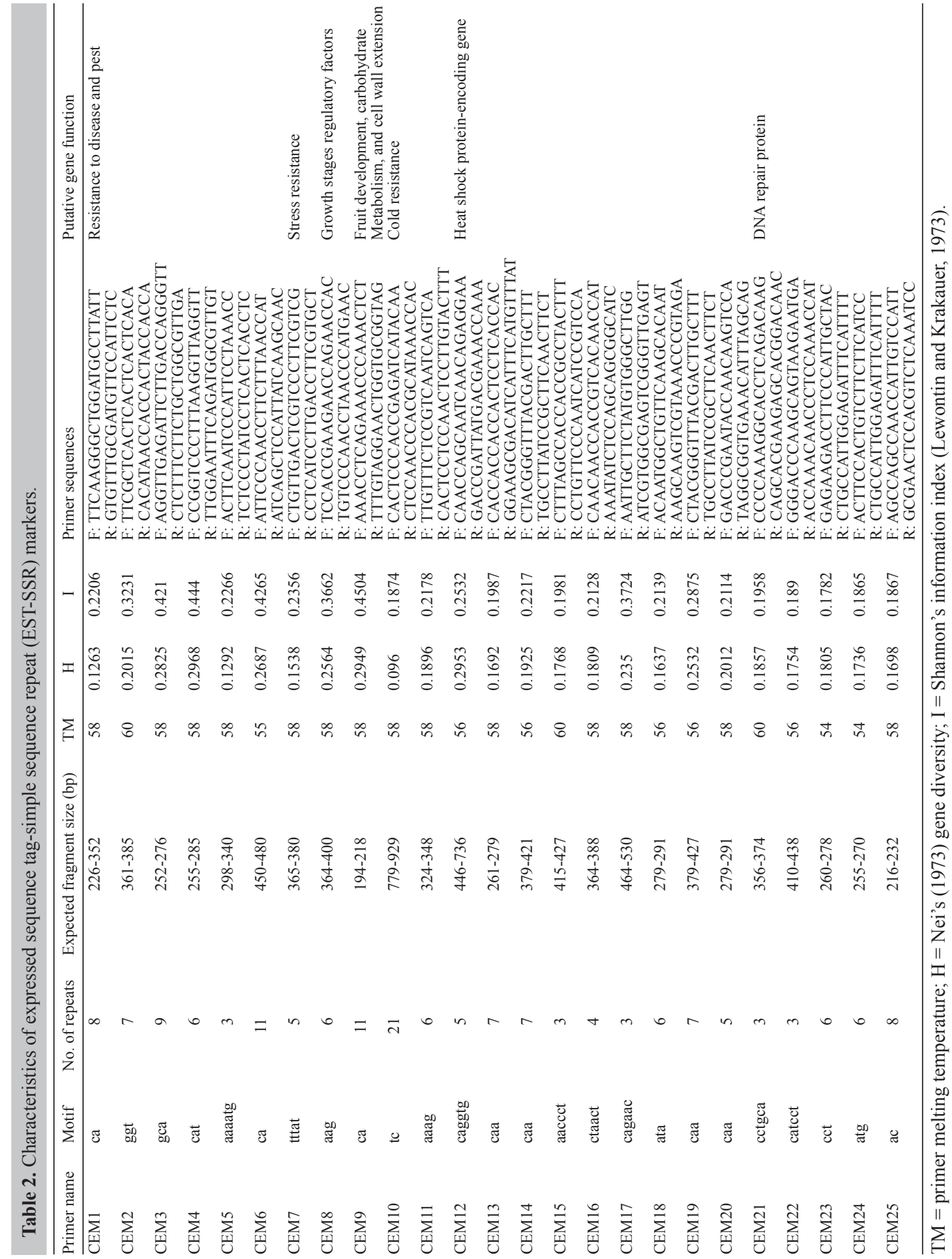

Genetics and Molecular Research 14 (3): 7578-7586 (2015) 
All 3 intergeneric hybrids (AP1, AP2, and AP3) of C. morifolium Pudidanfen and A. pacifica and the 3 intergeneric hybrids (AY1, AY2, and AY3) of C. morifolium Yulong and A. pacifica showed specific bands of the male and female parent (Table 3). AP1, AP2, and AP3 presented new bands, b5 and c5, which were absent from their parents, A. pacifica and Pudidanfen.
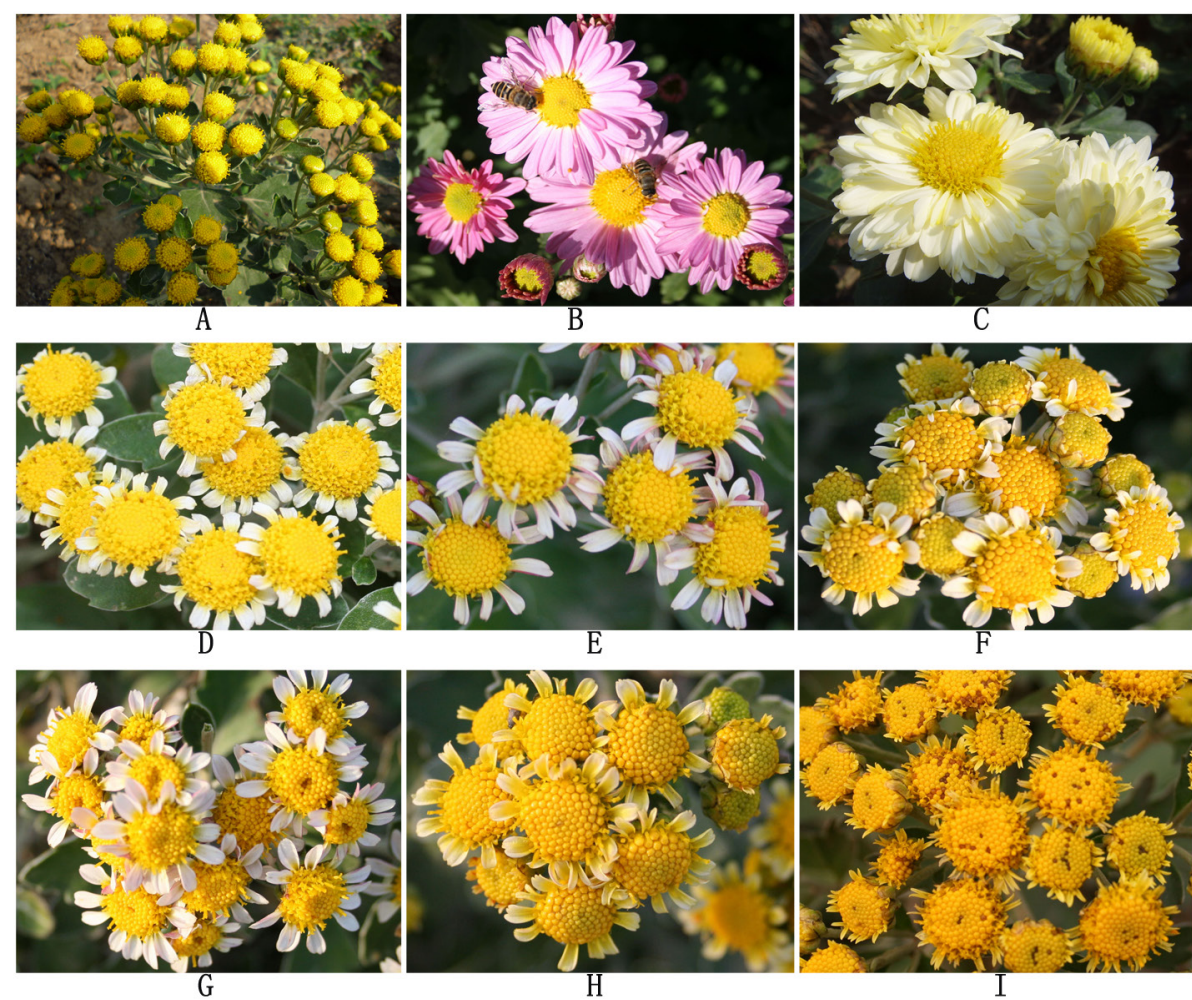

Figure 1. Ajania pacifica, Chrysanthemum morifolium Pudidanfen, C. morifolium Yulong, and intergeneric hybrids. A. A. pacifica. B. C. morifolium Pudidanfen. C. C. morifolium Yulong. D. Intergeneric hybrid between $A$. pacifica and C. morifolium Pudidanfen 1 (AP1). E. AP2. F. AP3. G. Intergeneric hybrid between A. pacifica and C. morifolium Yulong 1 (AY1). H. AY2. I. AY3. The figures have been supplied in JPEG format which need to be shown at the end of the manuscript.

\begin{tabular}{|c|c|c|c|c|c|c|c|c|c|}
\hline \multirow[t]{2}{*}{ Marker } & \multicolumn{3}{|c|}{ Parents } & \multicolumn{6}{|c|}{ Intergeneric hybrids } \\
\hline & Ajania pacifica & Yulong & Pudidanfen & AY1 & AY2 & AY3 & AP1 & AP2 & $\mathrm{AP} 3$ \\
\hline $\begin{array}{l}\text { CEM2 } \\
\text { CEM4 }\end{array}$ & $\begin{array}{c}a_{5}, a_{6} \\
b_{2}, b_{4}, b_{6}\end{array}$ & $\begin{array}{l}a_{2}, a_{3}, a_{4}, a_{7} \\
b_{1}, b_{2}, b_{4}, b_{7}\end{array}$ & $\begin{array}{l}a_{1}, a_{2}, a_{5}, a_{6} \\
b_{1}, b_{2}, b_{3}, b_{4}\end{array}$ & $\begin{array}{c}a_{3}, a_{4}, a_{5} \\
\mathrm{~b}_{1}, b_{2}, b_{3}, b_{4}, b_{7}\end{array}$ & $\begin{array}{c}a_{3}, a_{4}, a_{6}, a_{7} \\
b_{2}, b_{4}\end{array}$ & $\begin{array}{c}a_{2}, a_{4}, a_{5}, a_{7} \\
b_{1}, b_{2}, b_{4}\end{array}$ & $\begin{array}{l}a_{2}, a_{3}, a_{4}, a_{5} \\
b_{1}, b_{2}, b_{4}, b_{5}\end{array}$ & $\begin{array}{c}a_{2}, a_{3}, a_{4}, a_{5}, a_{6} \\
b_{2}\end{array}$ & $\begin{array}{c}a_{1}, a_{2}, a_{3}, a_{4}, a_{3} \\
b_{2}, b_{4}, b_{5}, b_{7}\end{array}$ \\
\hline CEM9 & $c_{1}, c_{2}, c_{4}, c_{6}, c_{7}, c_{9}$ & $c_{2}, c_{4}, c_{8}, c_{9}$ & $c_{3}, c_{7}, c_{8}$ & $c_{1}, c_{2}, c_{4}, c_{6}, c_{8}, c_{9}$ & $c_{1}, c_{2}, c_{4}, c_{7}, c_{9}$ & $c_{2}, c_{4}, c_{6}, c_{7}, c_{9}$ & $c_{2}, c_{4}, c_{7}, c_{9}$ & $c_{2}, c_{4}, c_{5}^{c}, c_{6}, c_{7}$ & $c_{1}, c_{2}, c_{3}, c_{4}, c_{7}$ \\
\hline
\end{tabular}

Band size: $a_{1}: 361 \mathrm{bp}, a_{2}: 364 \mathrm{bp}, a_{3}: 367 \mathrm{bp}, a_{4}: 370 \mathrm{bp}, a_{5}: 373 \mathrm{bp}, a_{6}: 376 \mathrm{bp}, a_{7}: 379 \mathrm{bp}, b_{1}: 255 \mathrm{bp}, b_{2}: 261 \mathrm{bp}$, $b_{3}: 267 \mathrm{bp}, b_{4}: 273 \mathrm{bp}, b_{5}: 279 \mathrm{bp}, b_{6}: 276 \mathrm{bp}, b_{7}: 285 \mathrm{bp}, c_{1}: 194 \mathrm{bp}, c_{2}: 196 \mathrm{bp}, c_{3}: 200 \mathrm{bp}, c_{4}: 202 \mathrm{bp}, c_{5}: 204 \mathrm{bp}$, $c_{6}: 206 \mathrm{bp}, c_{7}: 210 \mathrm{bp}, c_{8}: 212 \mathrm{bp}$, and $c_{9}: 214 \mathrm{bp}$. 


\section{DISCUSSION}

EST-SSRs are not without their drawbacks, but they offer a number of clear benefits, including rapid and inexpensive development and high levels of cross-taxon portability (Ellis and Burke, 2007). In previous studies, EST-SSR markers were developed, and the transitivity to related species was tested. However, we sought to develop EST-SSR markers for Chrysanthemum and its closely related species and genera in this study to identify intergeneric hybrids of C. morifolium, Ajania, and Opisthopappus. Few gene sequences have been determined in Ajania and Opisthopappus. Thus, the ESTs of Chrysanthemum were exploited, and 25 ESTSSRs revealed polymorphism among the wild species and varieties of Chrysanthemum, Ajania, and Opisthopappus. Nei's gene diversity (0.0960-0.2968) and Shannon's information index (0.1782-0.4504) of the EST-SSRs showed a broad range, which indicated that the genetic diversity revealed by each EST-SSR was different. EST-SSRs could be exploited to facilitate evolutionary analyses in a wide variety of taxa. This approach may constitute an effective method for the analysis of species with only limited resources, such as some closely related genera of Chrysanthemum. These EST-SSR markers could be used to identify cultivars, accurately assess genetic relationships and diversity, efficiently tag and map desirable genes, and select superior genotypes early in Chrysanthemum and closely related species.

BLASTX searches against the nr protein database (NCBI) revealed that 7 SSR markertargeted ESTs have putative gene functions, such as disease-resistance and stress-resistance, which indicated that ESTs could be utilized to develop functional SSR markers. The application of EST-SSR markers to the identification of intergeneric hybrids was demonstrated and proved to be a valuable tool for the breeding of Chrysanthemum and Ajania plants.

The intergeneric hybrids of C. morifolium (Yulong and Pudidanfen) and A. pacifica showed specific bands of the male and female parent; these bands were consistent with their inheritance of acquired characteristics. For example, the hybrids all exhibited ray flowers that were inherited from C. morifolium because the inflorescence of $A$. pacifica is only composed of disc flowers. The thin and leathery leaf blades during pubescence were consistent with $A$. pacifica. Furthermore, a number of hybrids presented new bands that were absent in their parents, which indicated that the intergeneric hybrids generated a new genotype. Therefore, EST-SSRs can be developed for species that lack gene sequences or ESTs by utilizing ESTs of closely related species.

\section{ACKNOWLEDGMENTS}

Research supported by the 12th Five Years Key Programs for Science and Technology Development of China (\#2012BAD01B07, \#2013BAD01B07) and the Program of Joint Development with Beijing (2013).

\section{REFERENCES}

Abd El-Twab MH, Kondo K and Hong DY (1999). Isolation of a particular chromosome of Ajania remotipinna in a chromosome complement of an artificial F1 hybrid of Dendranthema lavandulifolia x Ajania remotipinna by use of genomic in situ hybridization. Chrom. Sci. 3: 21-28.

Bandopadhyay R, Sharma S, Rustgi S, Singh R, et al. (2004). DNA polymorphism among 18 species of Triticum-Aegilops complex using wheat EST-SSRs. Plant Sci. 166: 349-356. 
Bhat PR, Krishnakumar V, Hendre PS, Rajendrakumar P, et al. (2005). Identification and characterization of expressed sequence tags-derived simple sequence repeats markers from robusta coffee variety 'CxR' (an interspecific hybrid of Coffea canephora x Coffea congensis). Mol. Ecol. Notes 5: 80-83.

Chagné D, Chaumeil P, Ramboer A, Collada C, et al. (2004). Cross-species transferability and mapping of genomic and cDNA SSRs in pines. Theor. Appl. Genet. 109: 1204-1214.

Decroocq V, Favé MG, Hagen L, Bordenave L, et al. (2003). Development and transferability of apricot and grape EST microsatellite markers across taxa. Theor. Appl. Genet. 106: 912-922.

Deng YM, Chen SM, Chen FD, Cheng X, et al. (2011). The embryo rescue derived intergeneric hybrid between chrysanthemum and Ajania przewalskii shows enhanced cold tolerance. Plant Cell Rep. 30: 2177-2186.

Douzono M and Ikeda H (1998). All year round productivity of F1 and BC1 progenies between Dendranthema grandiflorum and D. shiwogiku. Acta Hortic. 454: 303-310.

Ellis JR and Burke JM (2007). EST-SSRs as a resource for population genetic analyses. Heredity 99: 125-132.

Fukai S (2003). Dendranthema species as chrysanthemum genetic resources. Acta Hortic. 620: 223-230.

Fukai S, Nagira T and Goi M (2000). Cross compatibility between Chrysanthemum (Dendranthema grandiflorum) and Dendranthema species native to Japan. Acta Hortic. 508: 337-340.

Gong L and Deng ZA (2010). EST-SSR markers for gerbera (Gerbera hybrida). Mol. Breed. 26: 125-132.

Gupta PK, Rustgi S, Sharma S, Singh R, et al. (2003). Transferable EST-SSR markers for the study of polymorphism and genetic diversity in bread wheat. Mol. Genet. Genomics 270: 315-323.

Gutierrez MV, Vaz Patto MC, Huguet T, Cubero JI, et al. (2005). Cross-species amplification of Medicago truncatula microsatellites across three major pulse crops. Theor. Appl. Genet. 110: 1210-1217.

$\mathrm{Hu} \mathrm{X}$ and Zhao HE (2008). A preliminary study on distant hybridization of Opisthopappus with Chrysanthemum and Ajania. Modern Agr. Sci. 15: 13-14.

Kondo K, Abd El-Twab MH, Idesawa R, Kimura S, et al. (2003). Genome phylogenetics in Chrysanthemum sensu lato. In: Plant Genome: Biodiversity and Evolution (Sharma AK and Sharma A, eds.). Vol 1A. Science Publishers, Enfield, $117-200$.

Lewontin RC and Krakauer J (1993). Distribution of gene frequency as a test of the theory of the selective neutrality of polymorphisms. Genetics 74: 175-195.

Liu L, Guo W, Zhu X and Zhang T (2003). Inheritance and fine mapping of fertility restoration for cytoplasmic male sterility in Gossypium hirsutum L. Theor. Appl. Genet. 106: 461-469.

Morgante M and Olivieri AM (1993). PCR-amplified microsatellites as markers in plant genetics. Plant J. 3: 175-182.

Nei M (1973). Analysis of gene diversity in subdivided populations. Proc. Natl. Acad. Sci. U. S. A. 70: 3321-3323.

Ohashi H and Yonekura K (2004). New combinations in Chrysanthemum (Compositae-Anthemideae) of Asia with a list of Japanese species. J. Jpn. Bot. 79:186-195.

Pashley CH, Ellis JR, McCauley DE and Burke JM (2006). EST databases as a source for molecular markers: lessons from Helianthus. J. Hered. 97: 381-388.

Saha MC, Mian MAR, Eujayl I, Zwonitzer JC, et al. (2004). Tall fescue EST-SSR markers with transferability across several grass species. Theor. Appl. Genet. 109: 783-791.

Shibata M, Kawata J, Amano M, Kameno T, et al. (1988). Breeding process and characteristics of 'Moonlight', an interspecific hybrid between Chrysanthemum morifolium Ramat. and C. pacificum Nakai. Bull. Natl. Res. Inst. Veg. Ornam. Plant Tea Ser. A 2: 257-277.

Thiel T, Michalek W, Varshney RK and Graner A (2003). Exploiting EST databases for the development and characterization of gene-derived SSR-markers in barley (Hordeum vulgare L.). Theor. Appl. Genet. 106: 411-422.

Varshney RK, Graner A and Sorrells ME (2005). Genic microsatellite markers in plants: features and applications. Trends Biotechnol. 23: 48-55.

Zane L, Bargelloni L and Patarnello T (2002). Strategies for microsatellite isolation: a review. Mol. Ecol. 11: 1-16.

Zhang F, Chen SM, Chen FD, Fang WM, et al. (2011). SRAP-based mapping and QTL detection for inflorescence-related traits in chrysanthemum (Dendranthema morifolium). Mol. Breed. 27: 11-23.

Zhao HE, Liu ZH, Hu X, Yin JL, et al. (2009). Chrysanthemum genetic resources and related genera of Chrysanthemum collected in China. Genet. Resour. Crop Evol. 56: 937-946. 